\section{The Principle of Language Politeness in the Discourse of Husband-Wife Dialogue at Toronge, Baranti District of Sidenreng Rappang Regency}

\author{
1 Harmita Sari \\ 2 Sukmawati Tono Palangngan \\ 3 Samsinar \\ 4 Pancana Beta
}

123 Universitas Muhammadiyah Palopo, Indonesia

4 Universitas Cokroaminoto Palopo, Indonesia

\begin{abstract}
\section{Keywords}

politeness

discourse

dialogue
\end{abstract}

The purpose of this study was to determine the principle of language politeness in the discourse of husband-wife dialogue in the village community. The sources of data in this study were the husband and wife community of the Tonronge Village, Baranti District, Sidenreng Rappang Regency. This type of research used qualitative descriptive research to clearly describe the form of the principle of language politeness. Data collection techniques consisted of observation, recording, tapping techniques, and documentation. The results showed that the principle of language politeness in society in the discourse of husband-wife dialogue in the community reflects the implementation of the cultural values of "siri" as a central value. The use of special vocabulary, such as taalani (please get it), ta (yours), iye (yes), ki (you) shows politeness in language.

\section{Ethical Lingua}

Vol. 7, No. 2, 2020

ISSN 2355-3448 (Print)

ISSN 2540-9190 (Online)

Corresponding Email

Harmita Sari

harmitasari@umpalopo.ac.id

Article's History

Submitted 1 October 2020

Revised 6 October 2020

Accepted 6 October 2020

DOI

10.30605/25409190.221

Copyright (๑) 2020

The Author(s)

This article is licensed under CC BY-NC-SA 4.0 License

\section{(cc) EY-NC-SA}




\section{The Principle of Language Politeness in the Discourse of Husband-Wife Dialogue at Toronge, Baranti District of Sidenreng Rappang Regency}

Language is a means by which humans communicate. In accordance with its function, language has the role of conveying messages between humans and others. Human beings use language to interact each other. Chaer \& Agustina (2004) stated that the function of language is a tool for interacting or as a means of communication, in the sense that language is used to convey information, feelings, ideas, or concepts. Language as a means of communication can also be used to exchange opinions, discuss, or discuss the problems faced. (Sari \& Maming, 2019) the problems of language and literature in Indonesia relate to the three main issues, namely the problem of Indonesian language, regional languages, and foreign languages. These three topics have their respective positions and functions. Indonesian is the national language and the state language. As the State language, Indonesian functions as; (1) state official language, (2) official introductory language in educational institutions, (3) advice on planning and implementation of development in conjunction with government, and (4) advice on cultural development and the use of science and modern technology (Nurjamal, Sumirat, \& Darwis, 2011).

If the culture-norm system way of discussing a person does not conform to the norm, then it will get negative values, for example, being arrogant, arrogant, indifferent, selfish, immodest, even uncultured. Thus, it is possible to define a number of different general principles to be favored in social interaction in a given culture. Some general principles include the nature of wisdom, generosity, humility, and sympathy for others (Yule, 2011).

Interpersonal relationships do not seem easy to create and realize effective communication. Effective communication reflects the quality of communication of each individual married couple. Good communication quality from married couples can be achieved without being separated from obstacles / disturbances in the communication process (Pangaribuan, 2016). The communication process between individuals and husbands and wives who have just married is very important (Setiawan, 2020). The characteristics of effective interpersonal communication, according to the results of research in the field show that the characteristics of effective interpersonal communication occur when the communicator (husband) can know the communicant's (wife's) response directly or preferably and will definitely know whether the communication is positive, negative, and success or not. If it doesn't work, then the communicator can give the communicant the opportunity to ask questions as widely as possible (Ridwan \& Supratman, 2018).

Taking a closer look at the scope of communication science will show that the discussion related to communication will be very broad and almost indefinitely because the events of communication are so unique and must be carried out by humans in their daily lives. We can see in everyday life how someone applies the principles of politeness in language. For example, a husband and wife who are having a dialogue or chatting, sometimes one of the husbands and wives has failed to apply the principles of politeness in a discussion if one of them is unable to control their emotions. Sometimes the husband has failed to apply the 
principle of politeness to discuss in dialogue or to have a chat with his wife if he himself implements the principle of "he must obey or follow because I am the head of the house with his wife". As shown in the following examples:

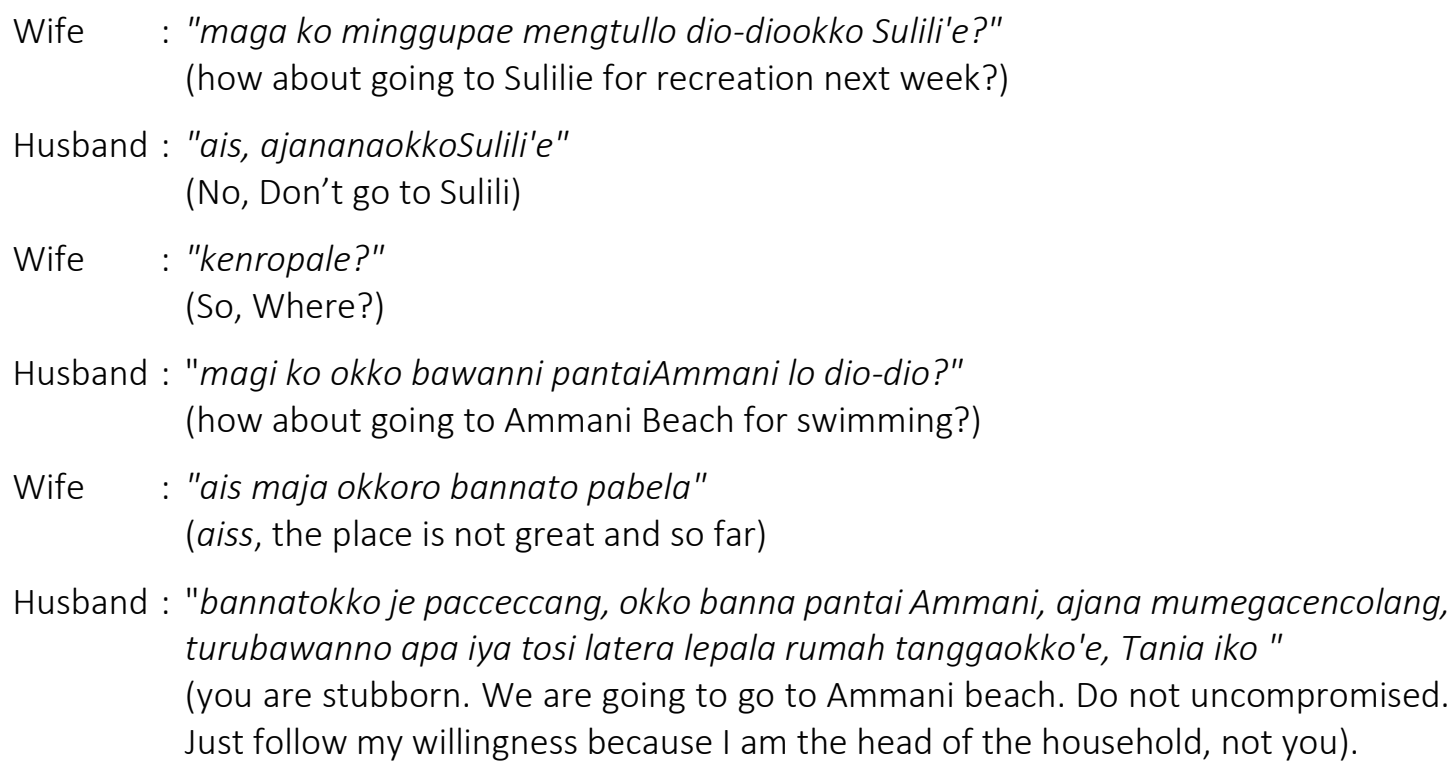

Husband: "bannatokko je pacceccang, okko banna pantai Ammani, ajana mumegacencolang, turubawanno apa iya tosi latera lepala rumah tanggaokko'e, Tania iko " (you are stubborn. We are going to go to Ammani beach. Do not uncompromised. Just follow my willingness because I am the head of the household, not you).

On these several points, it explains that in the language relationship, especially in husband and wife discourse, there are several uses of politeness principle. Based on the background, the problem question is, "How is the language politeness principle in husband-wife discourse at Tonronge Village, Baranti District, Sidenreng Rappang Regency?

\section{Method}

This research applied descriptive qualitative design. It produced descriptive data in form of written and spoken words from the respondent who were located at Tonronge village, Baranti District, Sidenreng Rappang Regency. This research conducted on the $16^{\text {th }}$ until $25^{\text {th }}$ January 2019. The collected data were in form of spoken discourse. The described discourse was the discourse that is showed the language politeness principle in husband-wife discourse. The data were collected through observation, recording, tapping technique, and documentation. Some collected data (the transcript that happen in society; the researchers reflection notes) were analyzed by; (1) Collecting Data, technique of data collection was non-test (Observation and documentation), and the discourse in society. The researchers collected the data at the most which is related to all aspect of language politeness principle in husband-wife discourse. (2) The data reduction. This technique applied data recording that got from the observation result. Then, the data were selected, be focused and be simplified in order to decide which data were taken. It aims to make it easier to take data that are considered in the principle of language politeness that occurs among the husband and wife discourse of the people of Tonronge Village, Baranti District, Sidenreng Rappang Regency. (3) The data Presentation. The collected presented data that has been collected and grouped in some parts based on the in order to make it easier to be understood and analyzed, the collected data from observation and documentation, and when the discourse between husband and wife happened. (4) Concluding the result analysis of the language politeness principle in husbandwife discourse. 


\section{Results}

The interview results of seven pairs of husband and wife at Tonronge village, Baranti District, Sidenreng Rappang Regency on the $16^{\text {th }}$ until $25^{\text {th }}$ Juni 2019 are as follows.

\section{Text 1}

$$
\begin{aligned}
& \text { Wife : Ohh...bapak naletteni mandre } \\
& \text { (ohhh Pak, let's have dinner) } \\
& \text { Husband : Manasuniga andretan di' } \\
& \text { (has the dinner ready?) } \\
& \text { Wife : Iye manasuni } \\
& \text { (yes, it's ready) } \\
& \text { Husband: Aga yandreang } \\
& \text { (what's the dish?) } \\
& \text { Wife : Padamobiasanna } \\
& \text { (as always). }
\end{aligned}
$$

\section{Text 2}

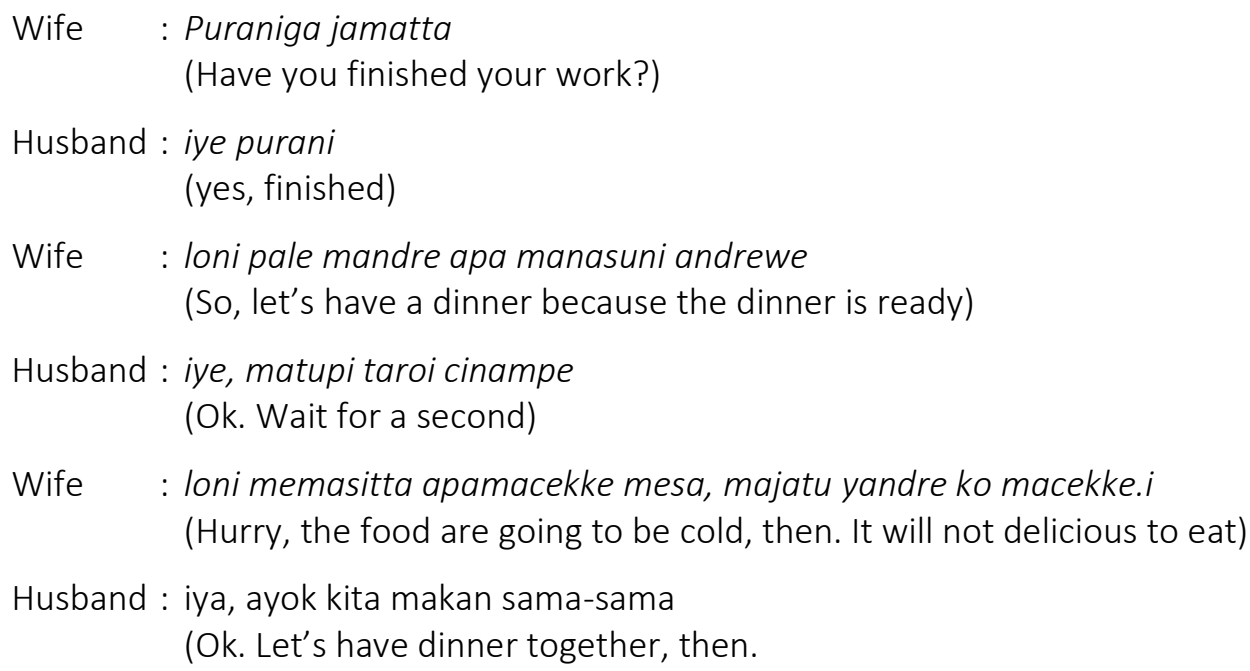

\section{Text 3}

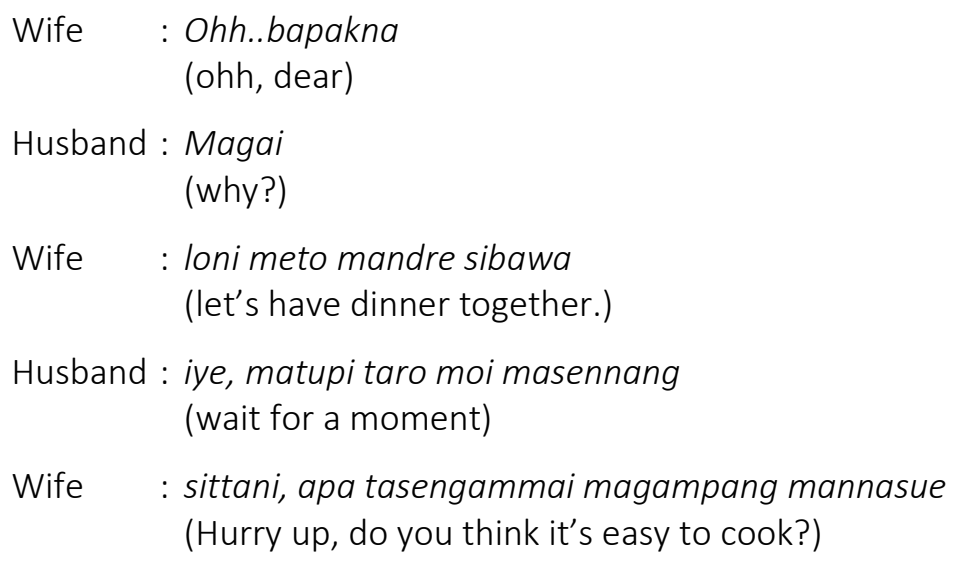




\section{Teks 4}

Wife : Manasuni andrewe, loni meto mandre

(The food is ready, let's have dinner)

Husband: lyye (Ok)

Wife : Melokiga yaleang?

(do you want to be served?)

Husband : idi sa ndi' komeloki

(yes dear, if it not burden you)

Wife : (take the food)

Husband: tudang toni ndi' tomandre sibawa

(have a seat, dear. Let's have dinner together)

\section{Text 5}

Wife : Tapajaini jamaii yatu, loni meto mandre

(Finished the work, let's have dinner)

Husband: Palenne moi jolo

(Just prepared it first.)

Wife : lenne manenni je'elo nime

(everything is ready)

Husband : iyo, taro moimasennang

(ok. Wait for a moment)

Alani jolo waimu

(just take the drinking water first)

\section{Text 6}

Wife : Agatu ijama, pappesauni jolo natomandre

(what are you doing, please finish it and let's have dinner)

Husband : Jolo cinampe apa ceddemani

(wait a minute. It's almost finished)

Wife : Majatu yandre andrewe ko macekke'i

(the food will not delicious if it getting cold)

Husband: Bannatokko je' pannennakeng, tomakkeda jolo samma (you are too talkative, l've told you wait a minute)

\section{Text 7}

Wife : Tasalai joloi yatu matupasi

(let it be, you may finished it later.)

Husband: Magaiko?

(why?)

Wife : Andreni jolo, apa lene manenni

(let's have dinner first, the food is ready)

Husband : Iye, jolo upakkapurai cinampemani

(Ok. Wait. It almost finished)

Wife : Asittaki apa maliwa sennaiya

(Hurry up. I'm starving)

Husband: lye (ok) 


\section{Discussion}

Based on the result, it is found that there are some language politeness principle found from the husband-wife discource such as "talani" (Please take me...), "ta" (yours), "iye" (yes), " $k$ (you).

The word 'talani' and 'alani' have the same meaning "take". The difference is the word "talani" is initiated by morpheme /ta-/ which means "you". Adding pronoun /ta/ is imperative as a polite linguistic formula in Sidrap Buginese Language. In contrast, if the morpheme /ta/ is not mentioned in imperative word such as in "alani" is showed the linguistic formula that less polite or unpolite because it contains a direct overall meaning, without a pronomen $/ \mathrm{tal}$.

The use of the morpheme 'iye' as in some of the above conversations is a manifestation of the cultural values of mappasikaraja 'mutual respect' or sipakalebbi 'mutual respect'. The word 'iye' is a lexical system which has a social meaning of politeness. The word 'iye' in Bugis community in Sidrap Regency is a word that has a social meaning of politeness. The word is used to affirm or approve of something that is conveyed by an older interlocutor or a respected interlocutor. In addition, the use of the morpheme 'iyo' also means 'iya'. The word iyo 'iya' is usually used to affirm or approve the statement of the other person who is the same age or approve the statement of the younger interlocutor.

The similar things can be seen in the use of the enclitic morpheme /ta-/ in the word 'baleta' 'your fish' in text 1 which is a sign of politeness, while the clitika morpheme /mu/ in the word 'waimu' in text 5 above seems impolite. Thus, the two morphemes can be used as indicators of linguistic politeness formula.

In text 7, the husband uses the word ' $k 0^{\prime}$ (magaiko) using a more casual or impolite greeting pattern. On the other hand, text 4 tends to choose a more polite form of greeting, such as '$\mathrm{ki}^{\prime}$ (you) and 'iyye' (yes). When it observed carefully the dialogue clearly shows that the aspect of seniority also has a crucial role in the pattern of politeness strategies chosen by the speech participants in interaction situations. Seniors (feeling more) are more likely to choose more casual greeting patterns so that they appear less polite, and the husband still chooses more polite greeting patterns because he respects the wife.

The principle of language politeness in the discourse of the Husband-Wife dialogue of the people of Tonronge Village, Baranti District, Sidenreng Rappang Regency reflects the implementation of the cultural values of "siri" as a central value. Based on these values, the Bugis people in Sidrap Regency created variations of speech as a strategy of language politeness. Moreover, language politeness is also influenced by the participant's status and situation factors. In connection with the linguistic formula, the forms of politeness in the language of Bugis people in Sidrap Regency are very varied, consisting of the use of pronouns as proclitic and enclitic, the use of special vocabulary, such as 'tabe', 'taddampenga' and honorific vocabulary in the form of greetings such as 'puang', 'iye', 'daeng', 'ndi', 'sappo', 'amure', and so on. At the syntactic level, the language politeness is also carried out by using hint strategy as the embodiment of the cultural meaning values of 'siri' and the cultural values set of 'Sipatangngari, Sipakaraja and Sipakaleb'i. 


\section{Conclusion}

Based on the results of research and discussion, it can be concluded that the principle of language politeness in the discourse of the husband-wife discourse of the people of Tonronge Village, Baranti District, Sidenreng Rappang Regency reflects the implementation of "siri" cultural values as a central value. The use of special vocabulary, such as taalani (please take it), ta (yours), iye (yes), ki (you) indicates the politeness in language.

\section{Acknowledgment}

N/A

\section{References}

Chaer, A. \& Agustina, L. (2004). Sosiolinguistik, Perkenalan Awal (Edisi Revisi). Jakarta: Rineka Cipta.

Nurjamal, D., Sumirat, W., \& Darwis, R. (2011). Terampil berbahasa. Bandung: Alfabeta.

Pangaribuan, L. (2016). Kualitas Komunikasi Pasangan Suami Istri Dalam Menjaga Keharmonisan Perkawinan. JURNAL SIMBOLIKA: Research and Learning in Communication Study, 2(1). http://ojs.uma.ac.id/index.php/simbolika/article/view/214/163

Ridwan, Z. A., \& Supratman, L. P. (2018). Pola Komunikasi Antarpribadi Pasangan Husband Wife Lanjut Usia. e-Proceeding of Management, 5(3), 4119-4143. https://core.ac.uk/download/pdf/299926363.pdf

Sari, H. \& Maming, R. (2019). Analisis Nilai Moral Dalam Teks Ma'parapa Prosesi Rampanan Kapa Di Tana Toraja. Jurnal Semantik, 8(2), 1-9. http://ejournal.stkipsiliwangi.ac.id/index.php/semantik/article/view/1557

Setiawan, G. A. (2020). Komunikasi Antarpribadi pada Pasangan Suami Istri Muda yang Istrinya Tetap Bekerja. Jurnal BECOSS, 2(1), 53-61. https://journal.binus.ac.id/index.php/BECOSS/article/view/6061

Yule, G. (2011). Pragmatik. Yogyakarta: Pustaka Pelajar. 